\title{
WORK-HOME INTERACTION OF WORKING FEMALES: WHAT IS THE ROLE OF JOB AND HOME CHARACTERISTICS?
}

\author{
ADELE VAN AARDE \\ CPRD Consulting Services (Pty) Ltd \\ South Africa \\ KARINA MOSTERT \\ ThinkWell: Economic Value of Wellness Research \\ Faculty of Economic and Management Sciences \\ North-West University \\ South Africa
}

Correspondence to: Karina Mostert

e-mail: karina.mostert@nwu.ac.za

\begin{abstract}
The objective of this study was to examine job characteristics and home characteristics associated with negative and positive work-home interaction of employed South African females. A total of 500 females from six provinces in South Africa participated in the study. Multiple regression analyses were used to analyse the data. The results indicated that negative work-home interference (WHI) was best predicted by job demands (including pressure, overload and time demands) and a lack of job resources (including autonomy, supervisor support, instrumental support and role clarity). Three job resources predicted positive WHI, including autonomy, supervisor support and colleague support. Negative home-work interference (HWI) was best predicted by pressure and a lack of autonomy at home, while positive HWI was best predicted by the presence of home pressure, but with support at home.
\end{abstract}

Keywords: Job characteristics, home characteristics, negative work-home interaction, positive workhome interaction

Family roles, workforce demographics and the relationship between work and family are changing. An increase in dual-career couples, single-parent households, and gender integration in organisations are just some of these changes, and the result is that more families find themselves struggling to juggle both work and family (Byron, 2005; Hammer, Colton, Caubet, \& Brockwood, 2002). Understanding the interaction of work and family issues has become increasingly important because of the increasing number of women in the workforce. Shifting economic and social circumstances and trends have impacted significantly on the traditional family structure, gender role prescriptions and the division of domestic labour (Naidoo, 2002). An increasing number of women are also included in the labour market because of economic necessity, a higher cost of living and personal fulfilment (U.S. Department of Labor, 1994).

In South Africa it is also evident that there is an increase in the number of women who have to adapt their traditional roles as they enter the workforce. The South African workforce began to comprise of more women after the 1994 election, as well as with the passing of new legislation such as the Employment Equity Act (Act No. 55 of 1998) (South Africa, 1998a) and the Skills Development Act (Act No. 97 of 1998) (South Africa, 1998b). According to the South African Department of Labour (2006), women are increasingly engaging with the South African economy through increased participation in the labour force. Statistics indicate that the number of males in the broad labour force increased by $35 \%$ from 1995 to 2005 , while the number of women increased by $59 \%$. Over the same period, the number of men in the narrow labour force increased by $36 \%$, while it increased by $59 \%$ for women, resulting in an increase in the women's share of the narrow labour force from $41,8 \%$ to $45,7 \%$. At the same time, the male share of the narrow labour force decreased from $58,2 \%$ to $54,3 \%$. In 2005, women accounted for almost six in 10 new members of the labour force in South Africa (South African Department of Labour, 2006).
An increasing number of women who have to fulfil dual roles by managing work and family issues are confronted with high pressures in both their work and home life, and many of their daily difficulties stem from job responsibilities that are incompatible with home or family responsibilities (Janssen, Peeters, De Jonge, Houkes \& Tummers, 2004). Constant interference between work and family can hinder a woman's career progression, decrease satisfaction with work, interfere with concentration on the job, increase absenteeism, and even lead to high turnover (Parasuraman \& Greenhaus, 1997).

Although employed women could experience negative interference between work and family, the interaction between these domains may also be positive in nature. Participating in multiple roles may provide the individual with more opportunities and resources that can be utilised in promoting growth and better functioning in other domains of life (Barnett, 1998; Grzywacz \& Marks, 2000). It was found, for example, that employed and married mothers experienced greater happiness and better physical health than unemployed and married mothers or employed single women without children (Waldron, Weiss \& Hughes, 1998). Employees who experience positive interaction between work and family are also more satisfied, committed and engaged workers (Montgomery, Peeters, Schaufeli \& Den Ouden, 2003; Mostert, 2006; Mostert, Cronjé \& Pienaar, 2006).

Different factors can have an influence on the interaction between work and home, including demographic characteristics, personality and attitudes (Geurts \& Demerouti, 2003). Research suggests that job and home characteristics also play a role in negative and positive work-home interaction (Geurts \& Demerouti, 2003; Montgomery et al., 2003; Mostert et al., 2006; Mostert \& Oosthuizen, 2006). However, research investigating the relationship between job and home characteristics and work-home interaction seems to be limited for employed women in South Africa. 


\section{Research objectives}

Based on the above discussion, the objectives of this study were 1) to determine which work and home characteristics play a role in the negative and positive work-home interaction of females working in the South African labour market; and 2) to determine the percentage of variance in work-home interaction explained by job and home characteristics.

\section{Work-home interaction}

The interaction between work and home (also called "nonwork") has been an important topic for many years and the awareness that the interaction between these two domains may create a major problem for families, employees, organisations and societies has grown in importance, particularly since the period of industrialisation (Westman \& Piotrkowski, 1999). A contemporary viewpoint is that "work" and "home" are not separate domains, but that they are highly interrelated. Work can be defined as a set of (prescribed) tasks that an individual performs while occupying a position in an organisation (Geurts \& Demerouti, 2003). Home (or non-work) may refer to activities and responsibilities within the family domain, as well as to activities and obligations beyond one's own family situation. It also involves activities (within and beyond the family domain) that cannot simply be considered leisure or spare time, because they involve (similar to the work domain) obligations and responsibilities (e.g. household activities, care-giving responsibilities and social obligation) (Geurts \& Demerouti, 2003)

Many scholars have theorised about how people manage the possible conflicting demands of work and family life, as well as the possible antecedents and consequences of such conflicts. The literature distinguishes between two main hypotheses (Edwards \& Rothbard, 2000; Frone, 2003; Geurts \& Demerouti, 2003). The first is the role scarcity hypothesis, which assumes that people possess limited and fixed amounts of resources (e.g. time and energy). Managing multiple roles (e.g. the role of employee, spouse and parent) may be problematic, as these roles draw on the same scarce resources. Work-family conflict (related terms are work-family interference and negative work-family spill-over) has been defined as "a form of interrole conflict in which role pressure from the work and family domains are mutually incompatible in some respect" (Greenhaus \& Beutell, 1985). This definition suggests that difficulties in combining work and family roles may arise either from time demands that make it physically impossible to be in two places at the same time (time-based conflict), from the spill over of strain from one domain to another (strain-based conflict), and/or from the incompatibility of behaviours requested in each domain (behaviour-based conflict)

The second hypothesis is the role enhancement hypothesis (also known as the enrichment, role accumulation, facilitation or positive spill-over hypothesis). This approach challenges assumptions that people possess fixed amounts of energy and that fulfilling multiple roles is inevitably associated with energy depletion and strain (Marks, 1977). It is proposed that fulfilling multiple roles produces (rather than depletes) resources (e.g. energy mobilisation, skill acquisition, greater self-esteem and positive affect) that facilitate functioning in both life spheres.

Thus far, research on the work-home interaction has not been driven by an overarching and integrating theoretical framework (Geurts, Taris, Kompier, Dikkers, Van Hooff \& Kinnunen, 2005; Grzywacs \& Marks, 2000; Westman \& Piotrkowski, 1999). Also, although the work-home interface would seem a much broader concept that also encompasses a positive side (the role enhancement hypothesis), very few studies have addressed the positive interaction between work and private life (Frone,
2003; Geurts \& Demerouti, 2003). Recently, the Survey WorkHome Interaction Nijmegen (SWING) (Geurts et al., 2005) was developed to measure both negative and positive interactions between the work and home domains. Work-home interaction is defined by Geurts et al. (2005, p. 322) as "an interactive process in which a worker's functioning in one domain (e.g. home) is influenced by (negative or positive) load reactions that have built up in the other domain (e.g. work)". Based on this definition, four dimensions of work-home interaction can be distinguished, namely 1) negative work-home interference (WHI), which refers to a situation in which negative load reactions that build up at work hamper a person's functioning at home; 2) positive WHI, defined as positive load reactions built up at work that facilitate functioning at home; 3) negative home-work interference (HWI), referring to negative load reactions developed at home that fetter a person's functioning at work; and 4) positive HWI, occurring when positive load reactions that develop at home facilitate functioning at work.

This definition and measurement of work-home interaction is based from a theoretical point of view on the Effort-Recovery (E-R) model (Meijman \& Mulder, 1998), and designed to enhance and extend the existing knowledge of work-home interaction. According to the E-R model, effort disbursement (e.g. task performance at work) is related to specific load reactions, including physiological, behavioural and subjective responses (e.g. changes in hormone secretion, energy levels and mood) that build up in the individual. Typically, these load reactions are reversible if recovery occurs after the effort had been invested and time had been taken for the psychobiological systems to stabilise. This shows that high demands from the one domain will not have unfavourable health consequences on the other domain, as long as adequate recovery takes place during or after these periods. However, when individuals do not recover fully from previous effort investments (in the job and/or home setting), they are required, while still in a sub-optimal state, to invest a compensatory effort to perform adequately when confronted with new demands in the work or home domain. If there is no time for recovery to take place and negative load reactions develop (such as strain and short-term psychosomatic health complaints), these may spill over into the other domain. In such circumstances, functional systems are not given a chance to stabilise at a baseline level, but are activated again. The increased intensity of the negative load reactions appeals even stronger to the recovery process. In the long term, a combination of persisting high demands and insufficient recovery may become manifest (e.g. health-related problems) and irreversible (Sluiter, Frings-Dresen, Van der Beek \& Meijman, 2001).

The same principles of the E-R model can also be applied to positive work-home interaction, since effort expenditure may be accompanied by positive load reactions. For example, if job resources are sufficient to deal with high job demands, energy may be replenished and mobilised rather than depleted. It will facilitate an individual's functioning in the home domain. Positive spillover (the translation of positive feelings) could originate in the work sphere and translate to the home sphere, and vice versa. Positive spillover may stimulate people to learn and grow in that specific domain, and therefore challenges the assumption that fulfilling multiple roles is associated with the depletion of fixed amounts of energy and strain (Geurts et al., 2005; Montgomery et al., 2003).

\section{Job and home characteristics}

According to the Job Demands Resources (JD-R) model (Bakker, Demerouti, De Boer \& Schaufeli, 2003; Demerouti, Bakker, Nachreiner \& Schaufeli, 2001), job characteristics can be organised in two broad categories, namely job demands and job resources. Job demands refer to those physical, psychosocial or organisational aspects of the job that require sustained physical 
and/or mental effort and are, therefore, associated with certain physiological and/or psychological costs. Examples are high work pressure (i.e. high work pace and tight deadlines), high physical or emotional demands, and role conflicts. Job resources refer to those physical, psychosocial or organisational aspects of the job that may be functional in meeting task requirements (i.e. job demands) and may reduce the associated physiological and/or psychological cost - and at the same time stimulate personal growth and development. Resources can be located in the task itself (e.g. performance feedback, skill variety, autonomy), as well as in the context of the task, for instance organisational resources (e.g. career opportunities, job security) and social resources (e.g. supervisor and co-worker support) (Hackman \& Oldham, 1976).

The JD-R model proposes that an employee's health and psychological wellbeing are the result of two relatively independent processes (Bakker et al., 2003; Demerouti et al., 2001). In the first process, job demands (e.g. work overload) in particular lead to constant overtaxing and, in the long term, to health problems. In the second process, the availability of job resources may help an employee to cope with demanding aspects of their work. At the same time it may also stimulate individuals to learn and grow in their job, leading to motivation, feelings of accomplishment, and organisational commitment. The mechanism operates similarly for home demands and home resources.

According to work done by Frone (2003), each dimension (i.e. positive/negative WHI and positive/negative HWI) has a unique relation to domain-specific antecedents and outcomes. It is hypothesised, for example, that the domain-specific antecedents of work-home conflict reside in the work domain, while the domain-specific antecedents of home-work conflict reside in the family domain. This has been verified by various researchers, who state that work characteristics are related to WHI and home characteristics are related to HWI (Frone, Yardley, \& Markel 1997; Grzywacs \& Marks, 2000; Kinnunen \& Mauno, 1998)

Several studies have shown that job demands and a lack of job resources are related to negative WHI (Bakker \& Geurts, 2004; Frone et al., 1997; Janssen et al., 2004; Kinnunen \& Mauno, 1998; Montgomery et al., 2003; Mostert \& Oosthuizen, 2006; Oldfield \& Mostert, 2007; Parasuraman, Purohit, Godschalk \& Beutell, 1996) and thus deplete functioning in the home domain. It is therefore hypothesised that job demands and job resources are significant predictors of negative WHI (Hypothesis 1).

Research strongly suggests that only job resources are related to positive WHI (Bakker \& Geurts, 2004; Marais, 2006). A study done by Grzywacs and Marks (2000) also found that job demands were unrelated to positive WHI. Based on these findings, it is hypothesised that job resources are significant predictors of positive WHI (Hypothesis 2).

There are not many findings in the literature on the relationship between home characteristics and negative or positive HWI. A study done by Montgomery et al. (2003) showed that home demands (quantitative, emotional and mental demands) are significantly related to HWI. It has also been reported that family demands, family-role conflict, family-role ambiguity, and family distress or dissatisfaction are positively related to HWI (Carlson \& Perrewe, 1999). However, Demerouti, Geurts and Kompier (2004) found that two forms of home resources, namely home support and home control, were not related to positive or negative HWI. It is therefore hypothesised that home demands and home resources are significant predictors of negative HWI (Hypothesis 3) and positive HWI (Hypothesis 4).

\section{RESEARCH METHOD}

\section{Research design}

A cross-sectional survey design was used to collect the data and to attain the research objectives. Cross-sectional designs are used to observe a group of people at a particular point in time - for a short period, such as a day or a few weeks (Du Plooy, 2002). The design is also used to assess interrelationships among variables within a population (Struwig \& Stead, 2001).

\section{Participants and procedure}

First, companies and hospitals in the Free State, Gauteng, KwaZulu Natal, North-West, Eastern Cape and Western Cape provinces were approached and asked if female managers and nurses working in the particular company/hospital could participate in the study. After permission was gained from companies and hospitals willing to participate in this study, lists of names and e-mail addresses of female managers were provided to the researchers. Hard copies of the questionnaires were distributed randomly in the hospitals. Participants with e-mail addresses were requested to send the electronic version of the questionnaire to two female friends who were working at least five hours a day. A return e-mail address was provided. For participants who completed a hard copy of the questionnaire, two additional hard copies with prestamped envelopes were provided, with the same request. Each questionnaire was accompanied by a letter explaining the rationale of the study and clear instructions on how to complete the questionnaire. If difficult words were used in some of the questions, an explanation of that particular word was provided at the bottom of the page. Confidentiality and anonymity were specifically emphasised. Participants were asked to complete the questionnaires and e-mail/post them to the given address. A total of 500 usable questionnaires was returned. Participants were asked to indicate their occupation. For ease of interpretation, participants were classified into five groups, including female managers (24\%), nurses $(27,6 \%)$, administrative personnel $(18,2 \%)$, females who do "people work" of some kind, e.g. educators, academics, psychologists, teachers, consultants, $(25,4 \%)$, and a diverse group of female workers, including hairdressers, beauticians, librarians, designers and caterers, $(4,8 \%)$. Table 1 shows other characteristics of the participants.

Table 1 shows that most of the participants were married (58,60\%). Of the total sample, $58,40 \%$ had a tertiary education. The majority of the females were white $(48,60 \%)$ or black $(33,80 \%)$ and spoke Afrikaans (41,20\%) and African languages (30,80\%). With regard to their career phase, most of the participants $(41,60 \%)$ were in their middle career phase (between the ages of 33 and 45). The majority of participants were married with children $(42,80 \%)$.

\section{Measuring instruments}

The following measurement instruments were used in the empirical study:

Job characteristics. On the basis of the literature, the most important demands and resources were identified and used to develop items to measure job characteristics, including Pressure (five items, e.g. "Do you have to work very fast?"); Overload (four items, e.g. "Do you have too much work to do?"); Time Demands (four items, e.g. "Do your colleagues help you to get the job done?"); Autonomy (eight items, e.g. "Do you have influence in the planning of your work activities?"); Supervisor Support (four items, e.g. "Do you get on well with your supervisor?"); Colleague Support (three items, e.g. "If necessary, can you ask your colleagues for help?"); Instrumental Support (four items, e.g. "Is there enough staff to do the work?"); and Role Clarity (four items, e.g. "Do you know exactly for what you are responsible and which areas are not your responsibilities?"). All items were scaled on a four-point scale, ranging from 1 (never) to 4 (always), with higher scores indicating higher levels of that particular dimension. 
TABLE 1

Characteristics of the participants

\begin{tabular}{|c|c|c|c|}
\hline ITEM & CATEGORY & FREQUENCY & PERCENTAGE (\%) \\
\hline \multirow[t]{4}{*}{ Career Phase } & Early & 152 & 30,4 \\
\hline & Middle & 208 & 41,6 \\
\hline & Late & 131 & 26,2 \\
\hline & Missing values & 9 & 1,8 \\
\hline \multirow[t]{4}{*}{ Ethnicity } & White & 243 & 48,6 \\
\hline & Black & 169 & 33,8 \\
\hline & Coloured & 80 & 16,0 \\
\hline & Missing values & 8 & 1,6 \\
\hline \multirow[t]{4}{*}{ Language } & Afrikaans & 206 & 41,2 \\
\hline & English & 135 & 27,0 \\
\hline & African & 154 & 30,8 \\
\hline & Missing values & 5 & 1,0 \\
\hline \multirow[t]{5}{*}{ Occupation } & Managers & 120 & 24,0 \\
\hline & Nurses & 138 & 27,6 \\
\hline & Admin & 91 & 18,2 \\
\hline & People & 127 & 25,4 \\
\hline & Diverse & 24 & 4,8 \\
\hline \multirow[t]{6}{*}{$\begin{array}{l}\text { Household } \\
\text { Situation }\end{array}$} & $\begin{array}{l}\text { Single without } \\
\text { children }\end{array}$ & 57 & 11,4 \\
\hline & Single with children & 92 & 18,4 \\
\hline & $\begin{array}{l}\text { Married without } \\
\text { children }\end{array}$ & 79 & 15,8 \\
\hline & Married with children & 214 & 42,8 \\
\hline & Living with parents & 36 & 7,2 \\
\hline & Missing values & 22 & 4,4 \\
\hline \multirow[t]{3}{*}{ Marital Status } & Married & 293 & 58,6 \\
\hline & Single & 185 & 37,0 \\
\hline & Missing values & 22 & 4,4 \\
\hline \multirow[t]{3}{*}{ Parental Status } & With children & 306 & 61,2 \\
\hline & Without children & 136 & 27,2 \\
\hline & Missing values & 58 & 11,6 \\
\hline \multirow[t]{3}{*}{ Education } & School education & 154 & 30,8 \\
\hline & Higher education & 292 & 58,4 \\
\hline & Missing values & 54 & 10,8 \\
\hline
\end{tabular}

Home characteristics. Items were developed to measure three home characteristics, namely Home Pressure (eight items, e.g. "Do you have to work very fast when you have to complete tasks at home?"); Home Autonomy (six items, e.g. "Do you have influence in the planning of your home activities?"); and Home Support (e.g. "If necessary, can you ask people in your private life (e.g. spouse, children, friends) for help with work at home?"). All items were scaled on a four-point scale, ranging from 1 (never) to 4 (always), with higher scores indicating higher levels of that particular dimension.

Work-home interaction. The Survey Work-Home Interaction Nijmegen (SWING) was used to measure work-home interaction (Geurts et al., 2005). The SWING is a 22-item work-home interference measure that measures four types of work-home interference, namely (1) negative WHI (eight items, e.g. "you do not have the energy to engage in leisure activities with your spouse/family/friends because of your job"); (2) positive WHI (five items, e.g. "you fulfil your domestic obligations better because of the things you have learned on your job"); (3) negative HWI (four items, e.g. "you have difficulty concentrating on your work because you are preoccupied with domestic matters"); and (4) positive HWI (five items, e.g. "you take your responsibilities at work more seriously because you are required to do the same at home"). All items were scored on a four-point frequency rating scale, ranging from " 0 " (never) to " 3 " (always). Several South African studies (Mostert \& Oldfield, 2008; Pieterse \& Mostert, 2005; Rost \& Mostert, 2007) have confirmed the four-factor structure of the SWING. These studies also found acceptable reliabilities (Cronbach's alpha) for the four scales of the SWING. For negative WHI, Cronbach's alpha varied from 0,85 to 0,90 ; for positive WHI, alpha ranged from 0,67 to 0,79 ; for negative WHI, alpha varied from 0,78 to 0,79 ; and for positive WHI, alphas ranged from 0,77 to 0,79 .

\section{Statistical analysis}

The statistical analysis was carried out with the SPSS program (SPSS Inc., 2006). Exploratory factor analysis and Cronbach alpha coefficients were used to asses the validity and reliability of the constructs that were measured in this study. Descriptive statistics (e.g. means, standard deviations, skewness and kurtosis) and inferential statistics were used to analyse the data. Pearson product-moment coefficients were used to specify the relationship between the variables. In terms of statistical significance, it was decided that the value would be set at a $95 \%$ confidence interval level ( $p \leq 0,05$ ). Effect sizes (Steyn, 1999) were used to decide on the practical significance of the findings. A cut-off point of 0,30 (medium effect) and 0,50 (large effect) was set for the practical significance of the correlation coefficients (Cohen, 1988). Multiple regression analysis was used to determine the predictive value of demands and resources on the four work-home interaction dimensions.

\section{RESULTS}

\section{Preliminary analyses}

Before analysing the data, exploratory factor analysis was used to determine the construct validity of the job and home characteristics questionnaires. The eigenvalues and scree plot showed eight factors (which explained $61,23 \%$ of the total variance) for job characteristics and three factors (explaining $50,98 \%$ of the total variance) for home characteristics. Common factor analyses with a varimax rotation for job characteristics and an oblimin rotation for home characteristics resulted in satisfying factor structures, reflecting the measured dimensions. Second order factor analyses were conducted for job and home characteristics. Both resulted in two factors, i.e. Job/Home Demands (including Pressure, Overload and Time Demands for job characteristics, and Home Pressure for home characteristics) and Job/Home Resources (including Autonomy, Supervisor Support, Colleague Support, Instrumental Support and Role Clarity for job characteristics and Home Autonomy and Home Support for home characteristics). Regarding the construct validity of a negative WHI/HWI, Coetzer (2006) tested competing structural models for work-home interaction in the same sample of females and confirmed the four-factor structure of the SWING.

\section{Descriptive statistics}

The descriptive statistics and alpha coefficients of the measuring instruments are shown in Table 2.

TABLE 2

Descriptive statistics and Cronbach alpha coefficients of the constructs

\begin{tabular}{lrrrrr}
\hline & $\boldsymbol{M}$ & SD & SKEWNESS & KURTOSIS & $\boldsymbol{\alpha}$ \\
\hline Pressure & 2,87 & 0,63 & $-0,09$ & $-0,62$ & 0,75 \\
Overload & 2,45 & 0,79 & 0,40 & $-0,67$ & 0,82 \\
Time Demands & 2,05 & 0,75 & 0,68 & $-0,05$ & 0,81 \\
Autonomy & 2,69 & 0,67 & $-0,13$ & $-0,54$ & 0,86 \\
Supervisor Support & 3,01 & 0,70 & $-0,61$ & 0,23 & 0,84 \\
Colleague Support & 3,01 & 0,64 & $-0,65$ & 0,74 & 0,80 \\
Instrumental Support & 2,56 & 0,69 & $-0,04$ & $-0,31$ & 0,77 \\
Role Clarity & 3,18 & 0,55 & $-0,68$ & 0,51 & 0,72 \\
Home Pressure & 2,59 & 0,71 & $-0,03$ & $-0,65$ & 0,88 \\
Home Autonomy & 3,31 & 0,59 & $-0,83$ & 0,44 & 0,75 \\
Home Support & 2,72 & 0,71 & 0,05 & $-0,84$ & 0,71 \\
Negative WHI & 1,21 & 0,63 & 0,27 & $-0,44$ & 0,86 \\
Positive WHI & 1,40 & 0,61 & 0,18 & $-0,15$ & 0,70 \\
Negative HWI & 0,58 & 0,55 & $1,28^{*}$ & $2,09^{*}$ & 0,76 \\
Positive HWI & 1,73 & 0,72 & $-0,18$ & $-0,58$ & 0,75 \\
\hline
\end{tabular}

* High skewness and kurtosis 
TABLE 3

Product-moment correlations of the constructs

\begin{tabular}{|c|c|c|c|c|c|c|c|c|c|c|c|}
\hline & 1 & 2 & 3 & 4 & 5 & 6 & 7 & 8 & 9 & 10 & 11 \\
\hline 1. Pressure & 1,00 & & & & & & & & & & \\
\hline 2. Overload & $0,55^{\star}$ & 1,00 & & & & & & & & & \\
\hline 3. Time Demands & $0,41^{*}$ & $0,36^{*}$ & 1,00 & & & & & & & & \\
\hline 4. Autonomy & $-0,05$ & 0,00 & $-0,07$ & 1,00 & & & & & & & \\
\hline 5. Supervisor Support & $-0,10^{*}$ & $-0,23^{*}$ & $-0,21^{\star}$ & $0,16^{*}$ & 1,00 & & & & & & \\
\hline 6. Colleague Support & $-0,12^{*}$ & $-0,20$ * & $-0,22^{*}$ & $0,14^{\star}$ & $0,51^{*}$ & 1,00 & & & & & \\
\hline 7. Instrumental Support & $-0,23^{*}$ & $-0,27^{*}$ & $-0,25^{\star}$ & $0,16^{*}$ & $0,36^{*}$ & $0,34^{*}$ & 1,00 & & & & \\
\hline 8. Role Clarity & $-0,26^{*}$ & $-0,41^{*}$ & $-0,22^{*}$ & $0,18^{\star}$ & $0,35^{\star}$ & $0,24^{*}$ & $0,30^{\star}$ & 1,00 & & & \\
\hline 9. Home Pressure & $0,24^{*}$ & $0,25^{\star}$ & $0,14^{*}$ & $-0,07$ & $-0,12^{\star}$ & $-0,14^{*}$ & $-0,17^{\star}$ & $-0,20^{*}$ & 1,00 & & \\
\hline 10. Home Autonomy & 0,03 & $-0,03$ & $-0,02$ & $0,27^{\star}$ & $0,09^{*}$ & $0,18^{*}$ & $0,12^{\star}$ & $0,17^{*}$ & $-0,07$ & 1,00 & \\
\hline 11. Home Support & 0,06 & 0,02 & $-0,03$ & $0,20^{*}$ & $0,18^{*}$ & $0,19^{*}$ & $0,09^{\star}$ & 0,00 & $-0,23^{*}$ & $0,17^{*}$ & 1,00 \\
\hline 12. Negative WHI & $0,46^{*}$ & $0,47^{*}$ & $0,49^{*}$ & $-0,24^{*}$ & $-0,33^{*}$ & $-0,28^{*}$ & $-0,35^{*}$ & $-0,40^{*}$ & $0,34^{*}$ & $-0,16^{*}$ & $-0,09^{\star}$ \\
\hline 13. Positive WHI & $-0,05$ & $-0,06$ & $-0,10^{*}$ & $0,16^{*}$ & $0,13^{*}$ & 0,01 & 0,06 & 0,01 & $0,13^{*}$ & 0,06 & 0,09 \\
\hline 14. Negative HWI & $0,16^{*}$ & $0,27^{*}$ & $0,19^{*}$ & $-0,16^{\star}$ & $-0,26^{*}$ & $-0,17^{*}$ & $-0,18^{\star}$ & $-0,31^{*}$ & $0,23^{\star}$ & $-0,16^{*}$ & $-0,08$ \\
\hline 15. Positive HWI & $-0,02$ & $-0,13^{*}$ & $-0,13^{*}$ & $0,12^{\star}$ & $0,17^{*}$ & 0,07 & 0,07 & 0,05 & $0,11^{*}$ & 0,04 & 0,04 \\
\hline
\end{tabular}

All correlations are statistically significant, $p<0,05$

"Alle correlations $0,30 \leq r \leq 0,49$ are practically significant (medium effect) (only correlations with the four work-home interaction dimensions are highlighted in bold) All correlations $\geq 0,50$ are practically significant (large effect) (only correlations with the four work-home interaction dimensions are highlighted in bold)

TABLE 4

TABLE 4
Multiple regression analyses with negative WHI as dependent variable

\begin{tabular}{|c|c|c|c|c|c|c|c|c|c|c|}
\hline \multicolumn{2}{|c|}{ MODEL } & \multicolumn{2}{|c|}{$\begin{array}{l}\text { UNSTANDARDISED } \\
\text { COEFFICIENTS }\end{array}$} & \multirow{2}{*}{$\begin{array}{c}\text { STANDARDISED } \\
\text { COEFFICIENTS } \\
\text { Beta }(\beta)\end{array}$} & \multirow[t]{2}{*}{$t$} & \multirow[t]{2}{*}{$p$} & \multirow[t]{2}{*}{$F$} & \multirow[t]{2}{*}{$R$} & \multirow[t]{2}{*}{$R^{2}$} & \multirow[t]{2}{*}{$\Delta R^{2}$} \\
\hline & & B & SE & & & & & & & \\
\hline \multirow[t]{4}{*}{1} & (Constant) & 1,21 & 0,05 & & 24,60 & 0,00 & 4,16 & 0,16 & 0,03 & 0,03 \\
\hline & Nurses vs. Managers & 0,15 & 0,08 & 0,10 & 1,98 & $0,05^{\star}$ & & & & \\
\hline & Nurses vs. Admin & $-0,15$ & 0,08 & $-0,09$ & $-1,87$ & 0,06 & & & & \\
\hline & Nurses vs. People & $-0,03$ & 0,07 & $-0,02$ & $-0,34$ & 0,74 & & & & \\
\hline \multirow[t]{7}{*}{2} & (Constant) & $-0,40$ & 0,12 & & $-3,42$ & 0,00 & 48,22 & 0,61 & 0,37 & 0,35 \\
\hline & Nurses vs. Managers & 0,08 & 0,07 & $-0,06$ & $-1,26$ & 0,21 & & & & \\
\hline & Nurses vs. Admin & $-0,06$ & 0,07 & $-0,04$ & $-0,94$ & 0,35 & & & & \\
\hline & Nurses vs. People & 0,02 & 0,06 & 0,02 & 0,35 & 0,73 & & & & \\
\hline & Pressure & 0,20 & 0,05 & 0,20 & 4,26 & $0,00^{*}$ & & & & \\
\hline & Overload & 0,21 & 0,04 & 0,27 & 5,66 & $0,00^{*}$ & & & & \\
\hline & Time Demands & 0,27 & 0,03 & 0,32 & 7,92 & $0,00^{*}$ & & & & \\
\hline \multirow[t]{12}{*}{3} & (Constant) & 1,30 & 0,24 & & 5,52 & 0,00 & 37,76 & 0,68 & 0,46 & 0,09 \\
\hline & Nurses vs. Managers & 0,03 & 0,06 & 0,02 & 0,46 & 0,65 & & & & \\
\hline & Nurses vs. Admin & $-0,06$ & 0,06 & $-0,04$ & $-0,96$ & 0,34 & & & & \\
\hline & Nurses vs. People & 0,05 & 0,06 & 0,04 & 0,90 & 0,37 & & & & \\
\hline & Pressure & 0,20 & 0,04 & 0,20 & 4,58 & $0,00^{*}$ & & & & \\
\hline & Overload & 0,13 & 0,04 & 0,16 & 3,53 & $0,00^{\star}$ & & & & \\
\hline & Time Demands & 0,22 & 0,03 & 0,26 & 6,67 & $0,00^{*}$ & & & & \\
\hline & Autonomy & $-0,16$ & 0,03 & $-0,17$ & $-4,82$ & $0,00^{*}$ & & & & \\
\hline & Supervisor Support & $-0,09$ & 0,04 & $-0,10$ & $-2,33$ & $0,02^{*}$ & & & & \\
\hline & Colleague Support & $-0,04$ & 0,04 & $-0,04$ & $-1,02$ & 0,31 & & & & \\
\hline & Instrumental Support & $-0,07$ & 0,04 & $-0,08$ & $-2,03$ & $0,04^{\star}$ & & & & \\
\hline & Role Clarity & $-0,14$ & 0,05 & $-0,12$ & $-3,07$ & $0,00^{*}$ & & & & \\
\hline
\end{tabular}

${ }^{*} p \leq 0,05$

From the results in Table 2, it can be seen that the alpha coefficients of all the measuring instruments were considered acceptable when compared to the guideline of $\alpha>0,70$ (Nunnally \& Bernstein, 1994).

\section{Product-moment correlations}

The results of the product-moment correlation coefficients between the constructs are reported in Table 3.

As expected, negative WHI was statistically and practically significantly related to job demands, including Pressure, Overload and Time Demands. Statistically significant relationships exist between negative WHI and all of the job resources, although practical significance was reached for the relationships with Supervisor Support, Instrumental Support and Role Clarity. Contrary to expectations, it seems that positive WHI has relatively weak relationships with job characteristics.
The only (statistically) significant relationship of positive WHI was with Time Demands, Autonomy and Supervisor Support. Negative HWI was statistically significantly related to Home Pressure and Home Autonomy, whereas positive HWI was only related to higher Home Pressure.

\section{Multiple regression analysis}

To determine which job characteristics and home characteristics predict the four types of work-home interaction, four multiple regression analyses were performed using the enter method. In a sample of 2040 South African employees from different occupational groups, De Klerk and Mostert (submitted) determined significant socio-demographic characteristics that are associated with each dimension (of which this sample was part). Therefore, we controlled for those specific characteristics found by De Klerk and Mostert (submitted) to be significant 
in the first step of each regression analysis. The results are reported in Tables 4, 5, 6 and 7 .

Table 4 summarises the regression analysis with sociodemographic characteristics, job demands and job resources as predictors of negative WHI. The entry of occupation variables at the first step of the regression analysis produced a statistically significant model $\left(F_{(3,496)}=4,16 ; p=0,00\right)$, accounting for approximately $3 \%$ of the variance. When job demands were entered in the second step of the regression analysis, a statistically significant model was produced $\left(F_{(6,93)}=48,22 ; p=0,00\right)$, which explained $37 \%$ of the total variance. More specifically, it seems that Pressure $(\beta=0,20 ; t=4,26 ; p=0,00)$, Overload $(\beta=0,27$; $t=5,66 ; p=0,00)$, and Time Demands $(\beta=0,32 ; t=7,92 ; p=0,00)$ predict negative WHI in this model. When job resources were entered in the third step of the regression analysis, a statistically significant model was produced again $\left(F_{(11,488)}=37,76 ; p=0,00\right)$, accounting for approximately $46 \%$ of the variance. It seems that, in addition to Pressure $(\beta=0,20 t=4,58 ; p=0,00)$, Overload $(\beta=0,16 ; t=3,53 ; p=0,00)$ and Time Demands $(\beta=0,26 ; t=6,67$; $p=0,00)$, a lack of Autonomy $(\beta=-0,17 ; t=-4,82 ; p=0,00)$, a lack of Supervisor Support $(\beta=-0,10 ; t=-2,33 ; p=0,02)$, a lack of Instrumental Support $(\beta=-0,08 ; t=-2,03 ; p=0,04)$ and a lack of Role Clarity $(\beta=-0,12 ; t=-3,07 ; p=0,00)$ predict negative WHI. Based on these findings, job demands and job resources are significant predictors of negative WHI, providing support for Hypothesis 1.

Table 5 summarises the regression analyses with sociodemographic characteristics and job resources as predictors of positive WHI. The entry of occupations, age and languages at the first step of the regression analysis produced a statistically significant model $\left(F_{(6483)}=3,60 ; p=0,00\right)$, accounting for approximately $4 \%$ of the variance. When job resources were entered in the second step of the regression analysis, a statistically significant model was produced $\left(F_{(11,478)}=5,09\right.$; $p=0,00)$, which explained $11 \%$ of the total variance. More specifically, it seems that Autonomy $(\beta=0,22 ; t=4,64 ; p=0,00)$, Supervisor Support $(\beta=0,15 ; t=2,85 ; p=0,01)$, and Colleague Support $(\beta=0,11 ; t=2,01 ; p=0,05)$ predict positive WHI. Based on these findings, job resources are significant predictors of positive WHI, providing support for Hypothesis 2.

Table 6 summarises the regression analyses with sociodemographiccharacteristics, homedemandsand homeresources as predictors of negative HWI. The entry of socio-demographic characteristics, occupation and language at the first step of the regression analysis produced a statistically significant mode $\left(\mathrm{F}_{(5,494)}=2,83 ; p=0,02\right)$, accounting for approximately $3 \%$ of the variance. When home demands were entered in the second step of the regression analysis, a statistically significant model was produced $\left(F_{(6493)}=7,65 ; p=0,00\right)$, accounting for $9 \%$ of the variance. More specifically, it seems that Home Pressure $(\beta=0,24 ; t=5,56$; $p=0,00)$ predicts negative HWI. When home resources were entered in the third step of the regression analysis, it presented a statistically significant model $\left(F_{(8,491)}=7,27 ; p=0,00\right)$, accounting for approximately $11 \%$ of the variance. In addition to Home Pressure $(\beta=0,23 ; t=5,20 ; p=0,00)$, it seems that a lack of Home Autonomy $(\beta=-0,14 ; t=-3,22 ; p=0,00)$ predicts negative WHI. Based on these findings, home demands and home resources are significant predictors of negative HWI, providing support for Hypothesis 3

Table 7 summarises the regression analyses with sociodemographic characteristics, home resources and home demands as predictors of positive HWI. The entry of occupation, age and language at the first step of the regression analysis produced a statistically significant model $\left(F_{(6,483)}=6,98 ; p=0,00\right)$, accounting for approximately $8 \%$ of the variance. When home resources were entered into the second step of the regression analysis, a statistically significant model was produced $\left(F_{(8,481)}=6,01 ; p=0,00\right)$, accounting for approximately $9 \%$ of the variance. More specifically, it seems that HomeSupport $(\beta=0,09$; $t=2,04 ; p=0,04)$ predicts positive HWI. When home demands were entered into the third step of the regression analysis, a statistically significant model was produced $\left(F_{(9,480)}=6,07\right.$; $p=0,00)$, accounting for approximately $10 \%$ of the variance. In addition to Home Support $(\beta=0,12 ; t=2,52 ; p=0,01)$, it seems that Home Pressure $(\beta=0,11 ; t=2,45 ; p=0,02)$ predicts positive HWI. Based on these findings, home demands and home resources are significant predictors of positive HWI, providing support for Hypothesis 4.

\section{DISCUSSION}

The general objective of this study was to investigate job and home characteristics associated with negative and positive workhome interaction of South African females. The Job DemandsResources (JD-R) model (Bakker et al., 2003; Demerouti et al.,

TABLE 5

Multiple regression analyses with positive WHI as dependent variable

\begin{tabular}{|c|c|c|c|c|c|c|c|c|c|c|}
\hline \multicolumn{2}{|c|}{ MODEL } & \multicolumn{2}{|c|}{$\begin{array}{l}\text { UNSTANDARDISED } \\
\text { COEFFICIENTS }\end{array}$} & \multirow{2}{*}{$\begin{array}{c}\text { STANDARDISED } \\
\text { COEFFICIENTS }\end{array}$} & \multirow[t]{2}{*}{$t$} & \multirow[t]{2}{*}{$p$} & \multirow[t]{2}{*}{$F$} & \multirow[t]{2}{*}{$R$} & \multirow[t]{2}{*}{$R^{2}$} & \multirow[t]{2}{*}{$\Delta R^{2}$} \\
\hline & & B & SE & & & & & & & \\
\hline \multirow[t]{7}{*}{1} & (Constant) & 1,44 & 0,09 & & 16,71 & 0,00 & 3,60 & 0,21 & 0,04 & 0,04 \\
\hline & Nurses vs. Managers & $-0,09$ & 0,08 & $-0,06$ & $-1,13$ & 0,26 & & & & \\
\hline & Nurses vs. Admin & 0,01 & 0,08 & 0,00 & 0,06 & 0,95 & & & & \\
\hline & Nurses vs. People & $-0,11$ & 0,07 & $-0,08$ & $-1,49$ & 0,14 & & & & \\
\hline & Age & 0,00 & 0,02 & 0,00 & 0,09 & 0,93 & & & & \\
\hline & Afrikaans vs. English & $-0,11$ & 0,07 & $-0,08$ & $-1,55$ & 0,12 & & & & \\
\hline & Afrikaans vs. African & 0,17 & 0,07 & 0,13 & 2,63 & $0,01^{\star}$ & & & & \\
\hline \multirow[t]{12}{*}{2} & (Constant) & 1,06 & 0,21 & & 4,96 & 0,00 & 5,09 & 0,32 & 0,11 & 0,06 \\
\hline & Nurses vs. Managers & $-0,18$ & 0,08 & $-0,12$ & $-2,28$ & $0,02^{\star}$ & & & & \\
\hline & Nurses vs. Admin & $-0,01$ & 0,08 & $-0,01$ & $-0,17$ & 0,87 & & & & \\
\hline & Nurses vs. People & $-0,16$ & 0,07 & $-0,11$ & $-2,13$ & $0,03^{\star}$ & & & & \\
\hline & Age & $-0,01$ & 0,02 & $-0,02$ & $-0,38$ & 0,71 & & & & \\
\hline & Afrikaans vs. English & $-0,10$ & 0,07 & $-0,08$ & $-1,45$ & 0,15 & & & & \\
\hline & Afrikaans vs. African & 0,18 & 0,06 & 0,14 & 2,86 & $0,00^{\star}$ & & & & \\
\hline & Autonomy & 0,19 & 0,04 & 0,22 & 4,64 & $0,00^{*}$ & & & & \\
\hline & Supervisor Support & 0,13 & 0,05 & 0,15 & 2,85 & $0,01^{\star}$ & & & & \\
\hline & Colleague Support & 0,10 & 0,05 & 0,11 & 2,01 & $0,05^{\star}$ & & & & \\
\hline & Instrumental Support & 0,01 & 0,04 & 0,02 & 0,28 & 0,78 & & & & \\
\hline & Role Clarity & 0,07 & 0,05 & 0,06 & 1,28 & 0,20 & & & & \\
\hline
\end{tabular}

$* p \leq 0,05$ 
TABLE 6

Multiple regression analyses with negative HWI as dependent variable

\begin{tabular}{|c|c|c|c|c|c|c|c|c|c|c|}
\hline \multicolumn{2}{|c|}{ MODEL } & \multicolumn{2}{|c|}{$\begin{array}{l}\text { UNSTANDARDISED } \\
\text { COEFFICIENTS }\end{array}$} & \multirow{2}{*}{$\begin{array}{c}\text { STANDARDISED } \\
\text { COEFFICIENTS } \\
\text { Beta }(\beta)\end{array}$} & \multirow[t]{2}{*}{$t$} & \multirow[t]{2}{*}{$p$} & \multirow[t]{2}{*}{$F$} & \multirow[t]{2}{*}{$R$} & \multirow[t]{2}{*}{$R^{2}$} & \multirow[t]{2}{*}{$\Delta \boldsymbol{R}^{2}$} \\
\hline & & B & SE & & & & & & & \\
\hline \multirow[t]{6}{*}{1} & (Constant) & 0,44 & 0,06 & & 7,73 & 0,00 & 2,83 & 0,17 & 0,03 & 0,03 \\
\hline & Nurses vs. Manager & 0,19 & 0,07 & 0,14 & 2,67 & $0,01^{*}$ & & & & \\
\hline & Nurses vs. Admin & 0,24 & 0,07 & 0,17 & 3,29 & $0,00^{*}$ & & & & \\
\hline & Nurses vs. People & 0,16 & 0,07 & 0,13 & 2,40 & $0,02^{\star}$ & & & & \\
\hline & Afrikaans vs. English & 0,02 & 0,07 & 0,02 & 0,32 & 0,75 & & & & \\
\hline & Afrikaans vs. African & 0,02 & 0,06 & 0,01 & 0,27 & 0,80 & & & & \\
\hline \multirow[t]{7}{*}{2} & (Constant) & $-0,04$ & 0,10 & & $-0,38$ & 0,71 & 7,65 & 0,29 & 0,09 & 0,06 \\
\hline & Nurses vs. Managers & 0,20 & 0,07 & 0,16 & 3,02 & $0,00^{*}$ & & & & \\
\hline & Nurses vs. Admin & 0,25 & 0,07 & 0,17 & 3,42 & $0,00^{*}$ & & & & \\
\hline & Nurses vs. People & 0,15 & 0,07 & 0,12 & 2,29 & $0,02^{*}$ & & & & \\
\hline & Afrikaans vs. English & 0,03 & 0,06 & 0,02 & 0,40 & 0,69 & & & & \\
\hline & Afrikaans vs. African & $-0,01$ & 0,06 & $-0,01$ & $-0,13$ & 0,90 & & & & \\
\hline & Home Pressure & 0,19 & 0,03 & 0,24 & 5,56 & $0,00^{*}$ & & & & \\
\hline \multirow[t]{9}{*}{3} & (Constant) & 0,47 & 0,20 & & 2,38 & 0,02 & 7,27 & 0,33 & 0,11 & 0,02 \\
\hline & Nurses vs. Managers & 0,21 & 0,07 & 0,17 & 3,19 & $0,00^{*}$ & & & & \\
\hline & Nurses vs. Admin & 0,22 & 0,07 & 0,16 & 3,13 & $0,00^{\star}$ & & & & \\
\hline & Nurses vs. People & 0,15 & 0,07 & 0,11 & 2,23 & $0,03^{*}$ & & & & \\
\hline & Afrikaans vs. English & 0,03 & 0,06 & 0,02 & 0,41 & 0,68 & & & & \\
\hline & Afrikaans vs. African & $-0,02$ & 0,06 & $-0,02$ & $-0,34$ & 0,74 & & & & \\
\hline & Home Pressure & 0,18 & 0,03 & 0,23 & 5,20 & $0,00^{*}$ & & & & \\
\hline & Home Autonomy & $-0,13$ & 0,04 & $-0,14$ & $-3,22$ & $0,00^{*}$ & & & & \\
\hline & Home Support & $-0,02$ & 0,04 & $-0,02$ & $-0,46$ & 0,64 & & & & \\
\hline
\end{tabular}

TABLE 7

Multiple regression analyses with positive HWI as dependent variable

\begin{tabular}{|c|c|c|c|c|c|c|c|c|c|c|}
\hline \multicolumn{2}{|c|}{ MODEL } & \multicolumn{2}{|c|}{$\begin{array}{l}\text { UNSTANDARDISED } \\
\text { COEFFICIENTS }\end{array}$} & \multirow{2}{*}{$\begin{array}{c}\begin{array}{c}\text { STANDARDISED } \\
\text { COEFFICIENTS }\end{array} \\
\text { Beta }(\beta)\end{array}$} & \multirow[t]{2}{*}{$t$} & \multirow[t]{2}{*}{$p$} & \multirow[t]{2}{*}{$F$} & \multirow[t]{2}{*}{$R$} & \multirow[t]{2}{*}{$R^{2}$} & \multirow[t]{2}{*}{$\Delta R^{2}$} \\
\hline & & B & SE & & & & & & & \\
\hline \multirow[t]{7}{*}{1} & (Constant) & 1,76 & 0,10 & & 17,49 & 0,00 & 6,98 & 0,28 & 0,08 & 0,07 \\
\hline & Nurses vs. Managers & $-0,23$ & 0,09 & $-0,13$ & $-2,54$ & $0,01^{*}$ & & & & \\
\hline & Nurses vs. Admin & $-0,06$ & 0,10 & $-0,03$ & $-0,64$ & 0,52 & & & & \\
\hline & Nurses vs. People & $-0,11$ & 0,09 & $-0,07$ & $-1,26$ & 0,21 & & & & \\
\hline & Age & 0,02 & 0,02 & 0,04 & 0,98 & 0,33 & & & & \\
\hline & Afrikaans vs. English & $-0,25$ & 0,08 & $-0,16$ & $-3,01$ & $0,00^{*}$ & & & & \\
\hline & Afrikaans vs. African & 0,17 & 0,08 & 0,11 & 2,23 & $0,03^{*}$ & & & & \\
\hline \multirow[t]{9}{*}{2} & (Constant) & 1,33 & 0,22 & & 5,93 & 0,00 & 6,01 & 0,30 & 0,09 & 0,08 \\
\hline & Nurses vs. Managers & $-0,24$ & 0,09 & $-0,14$ & $-2,69$ & $0,01^{*}$ & & & & \\
\hline & Nurses vs. Admin & $-0,05$ & 0,10 & $-0,03$ & $-0,55$ & 0,59 & & & & \\
\hline & Nurses vs. People & $-0,11$ & 0,09 & $-0,07$ & $-1,28$ & 0,20 & & & & \\
\hline & Age & 0,02 & 0,02 & 0,04 & 0,95 & 0,40 & & & & \\
\hline & Afrikaans vs. English & $-0,24$ & 0,08 & $-0,15$ & $-2,92$ & $0,00^{*}$ & & & & \\
\hline & Afrikaans vs. African & 0,21 & 0,08 & 0,13 & 2,63 & $0,01^{*}$ & & & & \\
\hline & Home Autonomy & 0,05 & 0,06 & 0,04 & 0,97 & 0,33 & & & & \\
\hline & Home Support & 0,09 & 0,05 & 0,09 & 2,04 & $0,04^{*}$ & & & & \\
\hline \multirow[t]{10}{*}{3} & (Constant) & 0,97 & 0,27 & & 3,64 & 0,00 & 6,07 & 0,32 & 0,10 & 0,09 \\
\hline & Nurses vs. Managers & $-0,23$ & 0,09 & $-0,14$ & $-2,62$ & $0,01^{*}$ & & & & \\
\hline & Nurses vs. Admin & $-0,05$ & 0,10 & $-0,03$ & $-0,54$ & 0,59 & & & & \\
\hline & Nurses vs. People & $-0,12$ & 0,09 & $-0,07$ & $-1,38$ & 0,17 & & & & \\
\hline & Age & 0,01 & 0,02 & 0,02 & 0,42 & 0,68 & & & & \\
\hline & Afrikaans vs. English & $-0,24$ & 0,08 & $-0,15$ & $-2,88$ & $0,00^{*}$ & & & & \\
\hline & Afrikaans vs. African & 0,20 & 0,08 & 0,13 & 2,58 & $0,01^{*}$ & & & & \\
\hline & Home Autonomy & 0,06 & 0,06 & 0,05 & 1,12 & 0,26 & & & & \\
\hline & Home Support & 0,12 & 0,05 & 0,12 & 2,52 & $0,01^{*}$ & & & & \\
\hline & Home Pressure & 0,12 & 0,05 & 0,11 & 2,45 & $0,02^{*}$ & & & & \\
\hline
\end{tabular}

${ }^{*} p \leq 0,05$

2001) and Effort-Recovery (E-R) model were used as theoretical frameworks.

The results indicated that both job demands and job resources were significant predictors of negative $\mathrm{WHI}$ and explained $46 \%$ of the variance. More specifically, pressure, overload, time demands, a lack of autonomy, a lack of supervisor support, a lack of instrumental support and low role clarity predicted negative WHI. These findings are consistent with the results of previous research (e.g. Bakker \& Geurts, 2004; Frone et al., 1997; Janssen et al., 2004; Montgomery et al., 2003; Mostert \& Oosthuizen, 2006; Oldfield \& Mostert, 2007). It was also found 
that job resources, especially autonomy and social support, have a negative relationship with negative WHI (Grzywacs \& Marks, 2000; Kinnunen \& Mauno, 1998; Parasuraman et al., 1996).

It seems that high job demands, specifically high pressure (e.g. working very fast, working very hard, intense concentration on a task for long periods), overload (e.g. too much work to do, left with work to do when you leave at the end of the day, struggle to complete all tasks for the day) and time demands (e.g. having to work overtime/irregular hours, socially undesirable hours) contribute to higher levels of negative WHI among female South Africans. In line with the E-R model, the practical implications of these findings are that females in particular experience negative interaction between their work and family life when they are exposed to high job pressure, work overload, time demands, have little or no autonomy and have little or no supervisor and instrumental support. Therefore, the negative effect created at work spills over to their home domain. As a result, females worry about their work at home and may fail to fulfil their domestic obligations. This may create an impairment process, as efficient recovery may be prevented (Demerouti et al., 2001).

Job resources were found to predict positive WHI, explaining $11 \%$ of the variance in positive WHI. More specifically, autonomy (e.g. freedom in carrying out your own work activities, deciding for yourself how much time you would like to spend on a task, solving problems that arise in your work yourself), supervisor support (e.g. getting on well with your supervisor, feeling appreciated by your supervisor, counting on your supervisor when you come across difficulties at work) and colleague support (e.g. counting on colleagues when you come across difficulties at work, asking colleagues for help) were found to predict positive WHI. This suggests that, among females, high autonomy, supervisor support and colleague support evoke positive feelings that spill over to and have a positive influence on the home domain. These results support previous findings that also found job resources to be related to positive WHI (Bakker \& Geurts, 2004; Grzywacs \& Marks, 2000; Marais, 2006; Rost, 2006)

In line with the E-R model, the practical implications of these findings are that females in particular experience positive interaction between their work and family life when they experience autonomy and receive support from their colleagues and supervisors at work. This positive effect created at work may spill over to the home domain. Therefore, females arrive at home in a more cheerful and positive state if they experienced a positive day at work. Having the resources at work may lead them to arrive home more relaxed and creates the opportunity for them to recover adequately after a day at work. It can also create a motivational process, as efficient recovery is facilitated, leaving the individual motivated and ready for the next day of work (Demerouti et al., 2001). The small percentage explained by job characteristics indicate that other factors may play a more important role when predicting positive WHI, including psychological involvement (i.e. the degree to which individuals identify with a social role and see it as important to their selfconcept) and personality variables (e.g. mastery, hardiness, positive affectivity, extraversion). It may be advisable to include other variables that may have a relationship with positive WHI in future studies.

Negative HWI was found to be significantly predicted by home demands and resources, which explained $11 \%$ of the variance in negative HWI. More specifically, it was found that home pressure (e.g. having a lot of work to do at home, having to work hard to get things done at home, having to work fast to complete tasks at home, having too much work to do) and a lack of home autonomy (e.g. deciding for yourself how to carry out your tasks at home, having influence over deciding when a certain task at home is to be completed, deciding how much time you want to spend on a task, having freedom in carrying out your activities at home) contributed to negative HWI. These findings suggests that it is particularly those females who experience high levels of home pressure and a lack of autonomy at home who experience negative feelings at home that spill over to their work domain. As a result, females worry about their home at work and may fail to fulfil their work obligations. Again, it can create an impairment process, as efficient recovery is prevented (Demerouti et al., 2001). As a result, the individual will lack the energy required to participate at work because her resources were not replenished at home. In a study done by Montgomery et al. (2003), it was also found that home demands (quantitative, emotional and mental demands) were significantly related to both negative and positive HWI.

Positive HWI was found to be significantly predicted by home demands and resources, which explained $10 \%$ of the variance in positive HWI. More specifically, home pressure (e.g. having lots of work to do at home, having to work hard to and/or very fast to get tasks done at home, finding it difficult to complete tasks at home and having an excessive amount of work to do at home) and home support (e.g. counting on people in your private life to help when you come across difficulties, people in your private life helping to get work done at home, having adequate equipment to carry tasks out at home) were found to predict positive WHI.

According to the E-R model, the practical implication of these findings is that females who are under high pressure at home, but also have high levels of support, experience more positive spill-over effects from their home to their work. Therefore, females who experience high levels of pressure at home, but who also have high levels of support, learn more skills that can create feelings of accomplishment. This positively influences their mood, which in turn spills over to their work domain.

The findings with regard to the relationship between home characteristics and HWI seem to support previous findings (i.e. Carlson \& Perrewe, 1999; Demerouti et al., 2004; Montgomery et al., 2003). However, home characteristics explained only a small percentage of the variance in negative and positive HWI. This can be due to the measures that were used, which only included home autonomy, home support and home pressure. Future research should include other home aspects, such as care-giving tasks, the amount of instrumental and physical support available, and whether the individual can influence the type of responsibilities she has to fulfil. Also, variables such as personality characteristics and attitudes should be considered as possible predictors of negative and positive HWI.

\section{LIMITATIONS AND RECOMMENDATIONS}

The first limitation of this study was the use of a cross-sectional design. The limitation with such a design is that the postulated relationships cannot be interpreted causally, which implies that no hard conclusions can be drawn with regard to the relationship between job and home characteristics and negative and positive work-home interaction. The second limitation was the exclusive use of self-report measures, which could increase the problem of common method variance. Since many multiple regression analyses were used to analyse the data, the possibility of chance capitalisation in this study cannot be ruled out completely. Finally, this study only included a few job and home characteristics. The JD-R model is capable of integrating several demands and resources, and it would thus be interesting to replicate the current findings in future studies using a broader range of job and home characteristics. Using a wider range of home characteristics would especially broaden the influence on the work-home interaction nexus. 
Certain recommendations can be made for future studies. The most important recommendation for future research is the use of longitudinal designs, as levels of work-family conflict fluctuate over time for many people. Longitudinal designs are used to validate the hypothesised causalities of the relationships further and to examine whether the reported relationships hold true over time. It will give researchers the opportunity to test for moderators of work-family conflict that have their sources outside of the target respondents. Demerouti et al. (2004) also suggest that, although the relationship between work and nonwork can be seen as a relatively new research domain, there is a need for longitudinal studies within this research domain.

An aspect that needs more attention is the unit of analysis. The family should be considered as the unit of analysis, instead of focussing on the individual (Frone, 2003). It should be borne in mind that an employee may affect not only his or her own performance, but also the performance of co-workers and the group. Previous studies have shown that psychological family involvement is positively related to HWI (Frone, 2003).

Personality variables (such as mastery, hardiness, positive affectivity and extraversion) should also be considered in the study of work-home interaction. Studies have found that high levels of hardiness, extraversion and self-esteem were associated with lower levels of WHI and HWI (Grandey \& Cropanzano, 1999; Grzywacz \& Marks, 2000). This reinforces the suggestion that other variable that could influence WHI/HWI should be included in future studies.

Specific recommendations can be made to organisations that employ females. Firstly, the effect of a demanding work environment on the experience of work-life interaction among females should be considered. In order to improve wellbeing, organisations need to explain and advise their employees on their wellbeing and related concepts (such as the role of demands and resources and the importance of recovery), as well as the outcomes thereof (e.g. negative WHI). This implies that employees must be able to identify certain demands or resources within their work environment (which may either hinder or help them in their functioning at work) and should be aware of the possible outcomes of these demands and resources. Furthermore, organisations should implement preventive organisation-based strategies to tackle high job demands and the lack of sufficient resources. Individualbased interventions to reduce WHI might also be an avenue to pursue. The current findings show that pressure, overload, time demands, lack of autonomy, lack of supervisor support and lack of instrumental support are the most prominent predictors for negative WHI, while the best predictors for positive WHI are autonomy, supervisor support and colleague support. Within the organisational environment, certain programmes or interventions should be aimed at preventing these specific job demands and improving the availability of these resources in order to decrease the risk of developing a negative WHI and promoting a positive WHI.

The home environment of the employees should also be considered. According to Bailyn and Harrington (2004) it is possible to arrange work in such as way that employees can be productive and are able to deal with their families at the same time. However, this would entail the redesign of work. With the redesign of work, deeply ingrained beliefs about work, families and gender roles are challenged. Organisations should also review their beliefs about work and ensure that the organisational culture is in line with their beliefs and policies of work-family issues. From a practical point of view, targets for the prevention of negative interaction could be based on clearer expectations for female employees, informal colleague support groups, and better management of work pressure and time. If organisations are focused on providing sufficient job resources and minimising job demands, the employees and the organisation will benefit.
Author's Note

The material described in this article is based on work supported by the National Research Foundation under reference number TTK2004072900009.

\section{REFERENCES}

Bailyn, L. \& Harrington, M. (2004). Redesigning work for workfamily integration. Work and Family, 7(2), 197-208.

Bakker, A.B., Demerouti, E., De Boer, E. \& Schaufeli, W.B. (2003). Job demands and job resources as predictors of absence duration and frequency. Journal of Vocational Behavior, 62, 341-356.

Bakker, A.B. \& Geurts, S.A.E. (2004). Towards a dual-process of work-home interference. Work E Occupations, 31, 345-366.

Barnett, R.C. (1998). Toward a review and reconceptualization of the work/family literature. Genetic, Social, and General Psychology Monographs, 124, 125-182.

Byron, K. (2005). A meta-analytic review of work-family conflict and its antecedents. Journal of Vocational Behavior, 67, 169-198.

Carlson, D.S. \& Perrewe, P.L. (1999). The role of social support in the stressor-strain relationship: An examination of workfamily conflict. Journal of Management, 25, 513-540.

Coetzer, L. (2006). Work-home interaction of South African females. Unpublished Masters dissertation. Potchefstroom: North-West University.

Cohen, J. (1988). Statistical power analysis for the behavioral sciences (Rev. Ed.). Orlando: Academic Press.

De Klerk, M. \& Mostert, K. (submitted for publication). Who are experiencing work-home interference? Examining sociodemographic differences in the South African context. SA Journal of Psychology.

Demerouti, E., Bakker, A.B., Nachreiner, F. \& Schaufeli, W.B. (2001). The job-demands resources model of burnout. Journal of Applied Psychology, 86, 499-512.

Demerouti, E., Geurts, S.A.E. \& Kompier, M.A.J. (2004). Positive and negative work-home interaction: Prevalence and correlates. Equal Opportunities International, 23, 6-35.

Du Plooy, G.M. (2002). Communication research: Techniques, methods and applications (2nd Ed.). Cape Town: Juta.

Edwards, J.R. \& Rothbard, N.P. (2000). Mechanisms linking work and family: Clarifying the relationship between work and family constructs. Academy of Management Review, 25, 178-199.

Frone, M.R. (2003). Work-family balance. In J.C. Quick \& L.E. Tetrick (Eds.). Handbook of occupational health psychology. Washington, DC: American Psychological Association.

Frone, M.R., Yardley, J.K. \& Markel, K.S. (1997). Developing and testing an integrative model of the work-family interface. Journal of Vocational Behavior, 54, 350-370.

Geurts, S.A.E. \& Demerouti, E. (2003). Work/non-work interface: A review of theories and findings. In M.J. Schabracq, J.A.M. Winnubst \& C.L. Cooper (Eds.). The handbook of work and health psychology. Chichester: Wiley, pp. 279-312.

Geurts, S.A.E., Taris, T.W., Kompier, M.A.J., Dikkers, J.S.E., Van Hooff, M.L.M. \& Kinnunen, U.M. (2005). Workhome interaction from a work psychological perspective: Development and validation of a new questionnaire, the SWING. Work and Stress, 19(4), 319-339.

Grandey, A.A. \& Cropanzano, R. (1999). The conservation of resources model applied to work-family conflict and strain. Journal of Vocational Behavior, 54, 350-370.

Greenhaus, J.H. \& Beutell, N.J. (1985). Sources of conflict between family and work roles. Academy of Social Behavior and Personality, 10(6), 121-134.

Grzywacs, J.G. \& Marks, N.F. (2000). Reconceptualizing the work-family interface: An ecological perspective on the correlates of positive and negative spillover between work and family. Journal of Occupational Health Psychology, 5, 111-126. 
Hackman, J.R. \& Oldham, G.R. (1976). Motivation through the design of work: Test of a theory. Organisational Behavior and Human Performance, 16, 250-279.

Hammer, L.B., Colton, C.L., Caubet, S.L. \& Brockwood, K.J. (2002). The unbalanced life: Work and family conflict. In I.C. Thomas \& M. Hersen (Eds.). Handbook of mental health in the workplace. London: Sage.

Janssen, P.P.M., Peeters, M.C.W., De Jonge, J., Houkes, I. \& Tummers, G.E.R. (2004). Specific relationships between job demands, job resources and psychological outcomes and the mediating role of negative work-home interference. Journal of Vocational Behavior, 65, 411-429.

Kinnunen, U. \& Mauno, S. (1998). Antecedents and outcomes of work-family conflict among employed women and men in Finland. Human Relations, 51, 157-177.

Marais, C. (2006). Work-home interaction and wellbeing in the South African Police Service. Unpublished doctoral dissertation. Potchefstroom: North-West University.

Marks, S.R. (1977). Multiple roles and role strain: Some notes on human energy, time and commitment. American Sociological Review, 42, 921-936.

Meijman, T.F. \& Mulder, G. (1998). Psychological aspects of workload. In P.J. Drenth, H. Thierry, \& C.J. de Wolff (Eds.). Handbook of work and organisational psychology (2nd Ed.) Hove, UK: Psychology Press.

Montgomery, A.J., Peeters, M.C.W., Schaufeli, W.B. \& Den Ouden M. (2003). Work-home interference among newspaper managers: Its relationship with burnout and engagement. Anxiety, Stress, and Coping, 16(2), 195-211.

Mostert, K. (2006). Work-home interaction as partial mediator between job resources and work engagement. Southern African Business Review, 10(1), 53-74.

Mostert, K., Cronje, S. \& Pienaar, J. (2006). Job resources, work engagement and the mediating role of positive work-home interaction of police officers in the North West Province. Acta Criminologica, 19(3), 64-87).

Mostert, K. \& Oldfield, G. (2008). Work-home interaction of employees in the mining environment. South African Journal of Economic and Management Sciences, 11(4).

Mostert, K. \& Oosthuizen, B. (2006). Job characteristics and coping strategies associated with negative and positive work-home interference in a nursing environment. South African Journal of Economics and Management Science, 9(4), 429-443.

Naidoo, A.V. (2002). Role salience of dual-career women managers. SA Journal of Industrial Psychology, 28, 69-74.

Nunnally, J.C. \& Bernstein, I.H. (1994). Psychometric theory (3rd Ed.). New York: McGraw-Hill.

Oldfield, G.R. \& Mostert, K. (2007). Job characteristics, ill health and negative work-home interference in the mining industry. South African Journal of Industrial Psychology, 33(2), 68-75.

Parasuraman, S. \& Greenhaus, J.H. (1997). The changing work of work and family. In S. Parasuraman \& J.H. Greenhaus (Eds.). Integrating work and family: Challenges and choices for a changing world. Westport, CONN: Quorum.

Parasuraman, S., Purohit, Y.S., Godschalk, V.M. \& Beutell, N.J. (1996). Work and family variables, entrepreneurial career success, and psychological well-being. Journal of Vocational Behavior, 48, 275-300.

Pieterse, M. \& Mostert, K. (2005). Measuring the work-home interface: Validation of the Survey Work-Home Interaction - Nijmegen (SWING) Instrument. Management Dynamics, 14(2), 2-15.

Rost, I. (2006). Work wellness of employees in the earthmoving equipment industry. Unpublished doctoral dissertation. Potchefstroom: North-West University.

Rost, I. \& Mostert, K. (2007). The interaction between work and home of employees in the earthmoving equipment industry: Measurement and prevalence. South African Journal of Industrial Psychology, 33(2), 54-61.

Sluiter, J.K., Frings-Dresen, M.H.W., Van der Beek, A.J. \& Meijman, T.F. (2001). The relation between work induced neuroendocrine reactivity and recovery, subjective need for recovery, and health status. Journal of Psychosomatic Research, 50, 29-37.

South Africa. (1998a). Employment Equity Act, Act 55 of 1998. Pretoria: Government Printer.

South Africa. (1998b). Skills Development Act, Act 97 of 1998 Pretoria: Government Printer.

South African Department of Labour. (2006). Women in the South African Labour Market: 1995-2005. Retrieved January 22, 2008, from the World Wide Web: http://www.labour. gov.za

SPSS Inc. (2006). SPSS 14.0 for Windows. Chicago, IL: SPSS Inc.

Steyn, H.S. (1999). Praktiese betekenisvolheid: Die gebruik van effekgroottes. Wetenskaplike bydraes - Reeks B: Natuurwetenskappe Nr. 117. Potchefstroom: PU vir CHO.

Struwig, F.W. \& Stead, G.B. (2001). Planning, designing and reporting research. Cape Town: Masker Miller Longman.

U.S. Department of Labor (1994). Handbook of women workers: Trends and issues. Washington, DC: Department of Labor Women's Bureau.

Waldron, I., Weiss, C.C. \& Hughes, M.E. (1998). Interaction effects of multiple roles on women's health. Journal of Health and Social Behavior, 50, 227-248.

Westman, M. \& Piotrkowski, C.S. (1999). Introduction to the special issue: Work-family research in occupational health psychology. Journal of Occupational Health Psychology, 4(4), 301-306 